\title{
"AEDEI Has Been and Is my life": An Interview with Professor Inés Praga Terente
}

\author{
María Amor Barros-del Río \\ University of Burgos, Spain \\ abarros@ubu.es
}

Copyright (c) 2017 by María Amor Barros-del Río. This text may be archived and redistributed both in electronic form and in hard copy, provided that the author and journal are properly cited and no fee is charged for access.

\begin{abstract}
In this interview, Professor Inés Praga Terente reviews the evolution of AEDEI from its origins to the present. As a founding member and its Chairperson until 2007, Professor Inés Praga has been a key force in the creation of AEDEI at a time when Ireland was not considered a field of study in the Spanish academia. In this interview, she recalls that a personal event in her life became the turning point that would lead her academic career towards Irish literature. Also, she recalls the timid and humble attempts made by her and a group of scholars to explore Irish literature and culture. Overcoming the difficulties and challenges that entailed the launching of an association, they finally succeeded in 2001 and AEDEI was born. In a personal and vivid style, she displays the clues that have made AEDEI not only a renowned forum for national and international lecturers, scholars and students, but also a community where passion and inspiration in Irish Studies are shared.
\end{abstract}

Key Words. Irish Studies, AEDEI, Inés Praga Terente

Resumen. En esta entrevista, la profesora Inés Praga Terente revisa la evolución de AEDEI desde sus orígenes hasta la actualidad. Como miembro fundador y su presidenta hasta 2007, la profesora Inés Praga ha sido un elemento clave en la creación de AEDEI en un momento en el que Irlanda aún no era considerada como campo de estudio académico. Según relata en esta entrevista, un evento personal de su vida fue el punto de inflexión que orientaría su carrera académica hacia la literatura irlandesa. También recuerda los primeros tímidos intentos de explorar la literatura y la cultura irlandesas desde su profesión hasta que, tras superar las dificultades y desafíos que conllevaba el lanzamiento de una asociación, AEDEI nació en 2001. En un estilo personal y distendido, la profesora Praga Terente desvela los elementos que han hecho de AEDEI no sólo un foro de renombre para profesores, académicos y estudiantes a nivel nacional e internacional, sino también una comunidad donde la pasión por los estudios irlandeses son compartidos.

Palabras clave. Estudios Irlandeses, AEDEI, Inés Praga Terente 
In 2016 we celebrated the fifteenth anniversary of the Spanish Association for Irish Studies (AEDEI). During these years, enthusiastic and committed scholars from Spain and abroad have given form to this community that has become part of our academic and personal lives. Indeed, AEDEI has much contributed to the relevance of Irish Studies in Spain, an achievement sustained by the personal passion, effort and engagement of its members. In my opinion, the enormous expansion of AEDEI and its present status as a consolidated organisation is based upon two complementary axes. On a yearly basis, an International Conference of the most outstanding quality has been held since 2001. Each time we have had the opportunity to exchange knowledge, projects and utopias with other colleagues who feel for Ireland beyond academic requirements. The variety of the topics discussed has undoubtedly meant a boost in the field of Irish Studies, as the subsequent peer-reviewed publications evidence. Complementing these milestones, the online journal, Estudios Irlandeses has become a much appreciated site for academic scholarship in the field. Since the release of its first issue (number 0) in March 2005, Estudios Irlandeses has achieved a high level of authorship and recently it has been awarded the Quality Seal for Excellence in Academic Journals by the Spanish Foundation for Science and Technology (FECYT). Thus, during its short life, AEDEI has flourished at home and abroad. In Spain, Irish Studies are present in academic programmes and doctoral studies have spread all around the country. At an international level, AEDEI has established beneficial relations and effective networks with relevant organisations such as EFACIS, ABEI and IASIL. All in all, we can affirm that AEDEI enjoys a thriving academic life and a promising future.

The origin of this successful history goes back to 2001, when a group of academics met in Burgos for the inaugural Conference Irlanda ante un nuevo milenio. There, Professor Inés Praga Terente's role was decisive for the foundation and development of AEDEI. She is Professor of English at the University of Burgos (Spain) and an outstanding academic in the field of Irish Studies. She is the author of Ireland in Writing. Interviews with Writers and Academics (in collaboration) (Amsterdam: Rodopi, 1998), Una belleza terrible: la poesía irlandesa contemporánea 1945-1995 (Barcelona: PPU, 1996) and Diccionario Cultural e Histórico de Irlanda (in collaboration) (Barcelona: Ariel, 1996), and she has edited La novela irlandesa del siglo XX (Barcelona, PPU: 2005) and Irlanda ante un nuevo milenio (Burgos: AEDEI, 2002). She has also participated in collective works: Family and Dysfunction in Contemporary Irish Narrative and Film. Marisol Morales Ladrón (ed.) (2016); A New Ireland in Brazil. Laura P.Z. Izarra and Beatriz Kopschitz (eds.) (2008); Análisis de género en los estudios irlandeses. María Elena Jaime de Pablos (coord.) (2007); Silverpowdered Olivetrees: Reading Joyce in Spain. Jefferey Simons et al., (cords.) (2003); and her many contributions can be found in journals such as Estudios Irlandeses, ES: Revista de Filología Inglesa, Revista Alicantina de Estudios Ingleses, ABEI Journal. The Brazilian Journal of Irish Studies, and Poetry Ireland. Her academic excellence in Irish Studies was acknowledged in 1998, when she was conferred with an Honorary Degree in Literature by the National University of Ireland (Cork) and since then she has directed many $\mathrm{PhD}$ dissertations that have significantly contributed to enrich the field of Irish Studies in Spain. In 2000 she was founding member of AEDEI and its first President from 2001 to 2007. Since then she has proudly been its Honorary Chairperson and a very active member. Added to her academic excellence, her genuine love for Ireland and her charming personality have been key ingredients for the creation and evolution of AEDEI. For the celebration of this anniversary we meet to revisit an adventure that has lasted more than fifteen years.

Naturally, I am very honoured to interview her and I cannot deny the deep emotions that surround this conversation as she has been my teacher and my mentor. When I ring at her door, Inés welcomes me with a broad smile and as we sit together at her place many memories of those hectic years come back to my mind. These walls have witnessed many 
gatherings of hard and passionate work. Hundreds of books on the shelves could talk of academic and friendly meetings and reunions. I have the feeling that time has not passed and yet, much has happened.

María Amor Barros-del Río: Fifteen years have passed since the foundation of AEDEI, but your love story with Ireland had begun much earlier. How was your first encounter with the island, its people and its culture?

Inés Praga Terente: My first visit to Ireland had nothing to do with the academic world. In 1985 an Irish colleague of mine, a language assistant at the University of Burgos, died suddenly. He was not married, he had no will, and he had left some properties behind. So, I decided to travel to Ireland to contact his relatives and try to help with such a complex matter, if possible. When I arrived at a small place near Cork, Fermoy, and met Irish people, I was pleasantly surprised. I guess I had expected to encounter places and people similar to those I had seen in Great Britain but in fact it was altogether different.

\section{MAB: In what sense?}

IPT: Well, to start with, it was a new land, a new territory. I soon realised it was a land to be discovered, to be deciphered, to be explored. There was magic there. There was youth. There was energy. Nothing to do with the somewhat exhausted old England I was more familiar with. At the same time, people were spontaneous, they were looking forward to talking to visitors at a time when foreigners were very scarce. In Fermoy I was, let's say, "exotic", and everybody wanted to ask me questions, to know about Spain. There was charm and warmth. They were very accessible and friendly. I had been in England many times before, in fact I had been working there as a language assistant for two years, but this feeling of proximity, of belonging, was unfamiliar to me.

\section{MAB: So you felt welcomed there...}

IPT: Oh, yes, extremely welcomed. Perhaps it was so because I was in a small place. But when I visited University College Cork at that time I had the same feeling and I noticed that the international presence was very scarce in those days (the Erasmus programme was about to begin, you know). There, I was lucky to meet Professor Terence Foley, an extraordinary Hispanist, an intellectual who could speak twelve languages but above all, a devoted and generous scholar who introduced me into Irish literature and culture. This meeting was crucial for my life. He gave me lots of books that I still treasure on these shelves, and I remember that he said to me: "These books are for you so that you let Spanish people know about our literature". That way Professor Foley discovered a new territory for me and the endless possibilities it offered. It was then that I decided to change my academic interests (focused on English literature so far) and walk that unknown path.

\section{MAB: At that time, were Irish Studies already present in the Spanish academic life?}

IPT: The truth is that Irish Studies was a non-existing area. Authors like Oscar Wilde, James Joyce or Samuel Beckett were studied within the curriculum of English literature. And from the point of view of culture or history, just a few references were made and always under the generic term of "British Culture and Civilization". 
MAB: So, under these circumstances, how did you and your colleagues manage to introduce Irish Studies within academic life and research?

IPT: I recall it as a very long and hard process. Above all, it was difficult to define and defend Irish literature as a distinct discipline. But we were very enthusiastic about it.

\section{MAB: Was it because the influence of the British tradition was still very strong?}

IPT: Of course. Spanish universities followed the path and the tradition of English Departments and Ireland was considered a beautiful and exotic island, but that was all. Joyce and Yeats, for instance, were studied within the English literary canon. So, for some time there were discussions and debates between people like us, who defended the individuality of Irish literature and culture, and those who believed it was simply part of the United Kingdom.

MAB: That is a very interesting process. I wonder what the nature of these debates were...

IPT: Well, we started creating a panel on Irish literature within AEDEAN Conferences (you know, the Spanish Association devoted to English and American Studies). As I was part of its Executive Board, I found it natural to explore this new field within that context. During that time, the papers presented and the debates that the field generated gave voice to a genuine interest but the people involved were still few, therefore the panel existed for only three or four years. Note that I am talking about Irish literature. By then that was the focus of our studies. Nowadays we know that Irish Studies must be approached from a multidisciplinary perspective.

But going back to those times, despite the difficulties a small group of scholars decided to apply for funding for a research project on Irish culture. And we got it!, though the proposal was a bit unorthodox! As a result of our work, a volume was published, Diccionario Cultural e Histórico de Irlanda, and somehow it made it easier to show the complexity of Ireland, not only from a literary point of view, but also from a historical, political and cultural perspective.

\section{MAB: I infer that both that research project and the release of the book were important landmarks in your career and in the conception of AEDEI. Was it so?}

IPT: Oh, yes. That is true. In fact, there were many factors, you know: solid research in the form of Ph.D. dissertations and publications and the organisation of Irish events. It all contributed to spreading an increasing interest in Ireland. For instance, I remember that here in Burgos we began to celebrate "Irish Weeks" and, although they were modest events, many people felt attracted by the variety of topics we were discussing and, of course, the allure of mystic Ireland played its role... Now that I think of it, we did many things with very little or no funding at all. Enthusiasm was very important, and has always been. And little by little all this gathered people from different universities who shared academic and personal interests. Mention should be made of the support provided by other institutions and colleagues. UCC was extremely helpful from the very beginning because we enjoyed an exchange of both students and Language Assistants for decades, and we organised several "Irish Weeks" in common. But the rest of the Irish Universities were also very supportive in our conferences and further projects. 
MAB: So it seemed only natural that a new association would bring together all these efforts...

IPT: Indeed. As I just said, Irish Studies raised expectations all over Spain. I should also mention that in 1998 I was conferred with an Honorary Degree in Literature by the National University of Ireland (Cork). I didn't expect it at all, I couldn't believe it! And after receiving it, I felt that I had an enormous debt with Ireland. Ireland had given me a lot, too much, and I decided to do something in return that would give continuity to Irish Studies in Spain. Let me clarify that I did not do it on my own, not at all. But I definitely was one of the promoters.

\section{MAB: And in May 2001 the Inaugural Conference was held in Burgos... Was it a turning point?}

IPT: Yes, it was. We were discussing the difficulties for some time, but I decided that we should host the first conference despite our lack of resources

\section{MAB: What do you mean?}

IPT: Well, you know that the University of Burgos is a small and young institution where English Studies, not to mention Irish Studies, were somewhat irrelevant. On the other hand, Burgos was a small city, not very well known internationally in spite of its amazing historic and artistic heritage. We thought it could be an additional attractiveness and I remember we managed to get some funding from a lot of local institutions. But most important of all, we counted with a group of young people, full of enthusiasm, generosity and energy (you were part of that group, so you know it all from the inside, don't you?), inspired by the idea of creating something important. To be true, we did not have much. But we did have love. We did have passion. And definitely they were enough!!!

The first AEDEI conference coincided with a singular moment for Ireland: It was the beginning of a new century, of a new millennium, and Ireland was entering a new phase. We were witnessing an Ireland of immigration rather than emigration, a Celtic Tiger Ireland instead of an impoverished Ireland. The Northern Ireland peace process was also a remarkable milestone... I think that Ireland was a shifting landscape at that moment and we were wise enough to think of Ireland in the plural, rather than in the singular, which would have meant a much more limited perspective. Thus, AEDEI was born and it adopted a multidisciplinary approach from the very beginning.

\section{MAB: How would you describe AEDEI's first years?}

IPT: Oh, well... they were difficult and glorious at the same time. Bureaucracy was a torture! It took us months to fulfil all the requirements, something that I had never expected. But it was glorious to be part of that process. AEDEI gave us a frame where we could explore, share, give and receive... And little by little we could feel that a community was being created.

\section{MAB: So the human factor has been relevant for AEDEI...}

IPT: Not only relevant. I'd say it has been its core, its heart. Human beings sharing interests, strength, expertise, dreams... and above all seeking and sharing new horizons. 


\section{MAB: Given the circumstances, you must have encountered some reluctance on the part of colleagues or academic institutions...}

IPT: Yes. I think they watched AEDEI's birth with surprise. Some people thought Ireland was too little to be considered at all. I'd rather describe it as "lack of faith" in our enterprise. But little by little we achieved visibility and recognition. We were convinced that only offering quality could we be noteworthy. For instance, we were very careful when choosing keynote speakers for our conferences so that the variety of fields and profiles was balanced. Also young scholars deserved our utmost attention as they were the future of AEDEI. Now you are the present. We tried to share our enthusiasm with them, and I think we succeeded.

\section{MAB: Yes, you did. I remember that AEDEI attracted many young people in those first years...}

IPT: It is true. There is always a time in academic life when you are a bit lost about your choices. We were just there for those young people. But also the plurality of approaches that AEDEI covers was an asset.

\section{MAB: What milestones would you highlight in AEDEI's fifteen years of existence?}

IPT: I think that AEDEI's national and international visibility is a result of the recognition and prestige it has achieved. Of course, none of this could have been possible without the joint effort of so many colleagues and institutions all over Spain. When I think of it, the list of people who helped would be endless, so let me just underline the generosity and efficiency of the organizers of the different AEDEI conferences and their universities in a chronological order: Barcelona, Almería, Málaga, Tarragona, Valladolid, A Coruña, Alcalá de Henares, Tenerife, Oviedo, Huelva, Extremadura, Bilbao, Granada, Zaragoza (http://aedei.es/?page_id=59). We have also had very special links with the University of Sao Paulo and ABEI (Brazilian Association of Irish Studies). And last, but never least, I would like to express my sincere gratitude to the Irish Embassy for their uninterrupted commitment and support over the years.

Also the solid and seminal publications of its members and the plurality of approaches in its conferences have been crucial. Let me explain this. We have always taken very seriously that every conference hosted a wide scope of first-rank personalities and scholars, ranging from journalists (Fintan O'Toole), historians (Roy Foster), poets (Paula Meehan), novelists (Hugo Hamilton) to activists (Ailbhe Smyth). These are but a few names that come to my mind now, but the list is endless and very varied, as you can see simply consulting our website. Nonetheless, I am proud to say that excellence did not need to be imported. I would like to mention that two distinguished members of AEDEI, Rosa González (University of Barcelona) and Munira Mutran (University of Sao Paulo), were also conferred with Honorary Degrees by the National University of Ireland (Galway and Maynooth respectively). But if you allow me, I'd dare say the jewel of the crown is our online journal Estudios Irlandeses, created and exemplarily edited by Rosa González until last March. In its twelve years of existence it has become a high-quality publication with contributions from all over the world. And there is also another issue I would like to remark: considering that many members of AEDEI are now in their 40s and early 50s, or even younger, we could affirm that an academic generation has grown up within AEDEI with similar ages, backgrounds and problems. A highly qualified and deeply committed membership that guarantees, not only the scholarly excellence, but the renewal of both the executive board and the editorship of our journal. 
MAB: You are right. That gives cohesion to it all...

IPT: Yes, of course. And continuity!

MAB: Looking forward into the future, what are AEDEI's opportunities and challenges in your opinion?

IPT: There are more challenges than opportunities, I am afraid. We are facing a new era. Paper is disappearing and the digital world is taking over. And the crucial question is why would people attend a conference nowadays? Everything is online, all the information you need is just a click away. So I think we must adapt to new formulas that only the human factor can provide. Challenges are many, indeed. But I am completely sure that we will evolve and that we will be a different but successful association in twenty years, let's say. Perhaps Alas! - I will not be there, but AEDEI will.

MAB: At present you are on sabbatical leave. Are your immediate plans related to Irish Studies?

IPT: Yes, of course, definitely. Lately I have been working on memory and literature and I am very interested in exploring the relation between memory and gender though so far I have got more questions than answers. $21^{\text {st }}$ century Ireland is also a topic that attracts my attention. Besides, my dear colleague and friend Rosa González has retired recently and we would like to do some work together, so at the moment we are discussing several possibilities. The truth is I cannot do without Ireland. It is part of me.

MAB: This takes me to my last question. At a personal level, what has AEDEI meant to you?

IPT: It has been and it is my life. Not just part of it. AEDEI is placed at the same level as my family and my friends. Should AEDEI disappear, I would feel some part of me is missing. I am very grateful to life for having allowed me, together with other colleagues, to create AEDEI. It has been a place to meet and this idea of belonging to a community is one of the reasons to go on. AEDEI will always be in my heart. Forever.

MAB: Inés, thank you very much for this wonderful interview. I have enjoyed it very much and I am sure our readers will also enjoy it and learn many things they didn't know about AEDEI and the history of Irish Studies in Spain.

IPT: Thank you. It has been a pleasure to share it all with you.

María Amor Barros-del Río is a lecturer at the University of Burgos, Spain. Her research focuses on gender studies and contemporary Irish fiction. She has both published and presented papers on related topics. She is the author of Metáforas de su tierra: Breve historia de las mujeres irlandesas (2004). Other areas of interest are critical pedagogy and language teaching. 